\title{
TROLLEY MOTION CONTROL BASED ON S-SHAPED VELOCITY PROFILE FOR QUAY CRANE CARGO OSCILLATION COMPARISON
}

\author{
Tomas EGLYNAS ${ }^{1}$, Marijonas BOGDEVIČIUS ${ }^{2}$, Arūnas ANDZIULIS ${ }^{3}$, Mindaugas JUSIS ${ }^{4}$ \\ ${ }^{1,2}$ Vilnius Gediminas Technical University, Vilnius, Lithuania \\ 1, 2, 3, ${ }^{4}$ Klaipéda University, Klaipéda, Lithuania
}

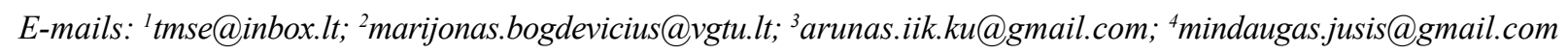

\begin{abstract}
Quay cranes are used to move containers from ship to store in minimum time so that the load reaches its destination without payload oscillation. During the operations, containers are suspended by cables and it's free to swing by motion. This paper investigates the two different velocity profiling techniques used for quay crane control and cargo stabilization. A laboratory scaled model of a crane is used to experimentally research, where the trolley acceleration is used as input, for suppressing the container sway. The residual cargo oscillation problems using different velocity profiles are discussed.
\end{abstract}

Keywords: container crane, loading process, container oscillations, experimental analysis, control systems, velocity profiling, trapezoidal profile, $\mathrm{S}$ shaped profile.

\section{Introduction}

A quay cranes play an important role in seaports for loading and unloading processes. They are used to move cargo from ship to store in a minimum time so that the load reaches its destination without swinging. The main control objective is to move the trolley to a required position as fast as possible with low payload oscillation (Elbadawy, Shehata 2015; Majid et al. 2013). In the container transportation industry, the loading velocity is an important issue as it translates into seaport productivity and efficiency. However, the external disturbances such as wind can easily initiate an oscillation. Uncontrolled oscillations may cause cargo stability and safety problems, especially during the deployment and retrieval phases of the container. Usually a skillful operator is responsible for quay crane loading and unloading operations. In precise container positioning by a human, who relies solely on his visual feedback, the operation can prove to be extremely challenging and time consuming (Wong et al. 2012). During the handling operations, the load is free to swing. If the swing exceeds a safe limit, it must be damped or the operation must be suspended until the oscillations decreases. It is practically impossible to completely remove payload oscillations in all possible situations. External disturbances such as wind, weather or operator actions can easily initiate an oscillation (Elbadawy, Shehata 2015). This unavoidable cargo swing frequently causes loading and unloading processes efficiency to drop, damages the containers or even causes accidents (Xing 2011). Nevertheless, the cargo handling operations required to move the container to a required position as fast as possible, however at higher transportation velocity, cargo oscillations become larger and complicate unloading process (Jaafar et al. 2012; Jaafar et al. 2013). In addition, this will cause the positioning inaccurate. To attain better positional accuracy of quay crane spreader, a control system that accounts for acceleration of trolley and oscillation of the cargo is required. One of most efficient and easiest ways in view of practical implementation is to use motion-profiling methods; however, the fast motion commonly conflicts to the smoothness of motion due to the residual oscillation. To reach the compromise between the velocity of motion and the oscillation reduction are one of the challenging tasks in motion profiling area for automated control systems (Rew et al. 2009). In order to increase the motion velocity it is necessary to control rapid increments or decrements of acceleration, which would cause high jerks. These jerks can be controlled. The jerk-limited profile is a common trajectory pattern used by modern motion systems and it is a time optimal solution of jerk limited body control. The jerk limitation is used for the limitation of deformations and vibrations induced by the reference trajectory, which can be generated to cancel or reduce the 
oscillations (Béarée 2014). The jerk-limited integration into the trapezoidal velocity profile gives us the symmetric or asymmetric s-shaped velocity profile. The smoothness of motion in these profiles depends from jerk duration. Longer duration increases smoothness, but decreases the time efficiency. For Better S-shaped velocity profile capabilities the experimental investigation must be performed.

In this paper, we propose the jerk-limited profile in view of the complex system of the quay crane where the cargo is suspended by cables to the case of acceleration caused residual oscillation. The results of experimental research of cargo oscillation during transportations process are compared to the trapezoidal motion profile caused residual oscillations. The main advantages of S-shaped velocity profile are discussed. In the sequel of the paper, we represent a new real time algorithm and control system behavior diagrams. The practical implementation of these algorithms and motion profiles that are based on the Arduino platform of the Atmel microcontroller is graphically represented.

In the next section, we present clear explanation regarding the ability of the S-shaped profile to cancel the residual oscillation and show how this motion profile can be used as a solution for quay crane cargo oscillation reduction. In this section, the new profile is analyzed and compared to the trapezoidal velocity profile.

\section{Motion profiles and control system}

Trapezoidal velocity profile (Fig. 1) is based on three-phase acceleration trajectory (Sun et al. 2012). This type of velocity profile is mostly used for overhead cranes (Xuebo et al. 2013; Sun et al. 2011; Sun et al. 2012). However, the infinite jerk problem, restricting the application of this profile. Three-phase acceleration control reduces system control capabilities comparing with S-shaped velocity profile (Fig. 2). S-shaped velocity profile mostly used for improving the smoothness of the motion by reducing the jerks in acceleration and deceleration phases (Rew et al. 2009; Wu, Xia 2014). This type of motion profile is based on seven-phase acceleration trajectory and jerk control. The jerk limited control profile is effective to reduce the excitation of the flexible modes. This profile ability to cancel undamped vibrations is first addressed (Béarée 2014).

In order to compare the experimental results based on S-shaped velocity profile and trapezoidal velocity profile, the mathematical calculations were performed, to establish similar conditions for the experiment. As depicted in Fig. 3, both profiles are calculated and compared. By the initial selectable input of the acceleration and deceleration duration for $Y$-axis $t_{\text {acc }}=4 \mathrm{~s}$. For the trapezoidal speed profile the accelerations value was calculated:

$$
a_{T R}=\frac{v_{\max }}{t_{\mathrm{acc}}} .
$$

Then the S-profile max acceleration was calculated:

$$
a_{\max }=\frac{a_{T R}}{1-\left(j_{\%} \cdot 0,005\right)},
$$

here $j_{\%}-$ selected initial condition value for jerk duration and its equal $50 \%$. The jerk constant is calculated:

$$
j=\frac{2 \cdot a_{\mathrm{max}} \cdot 100}{t_{\mathrm{acc}} \cdot j_{\%}} .
$$

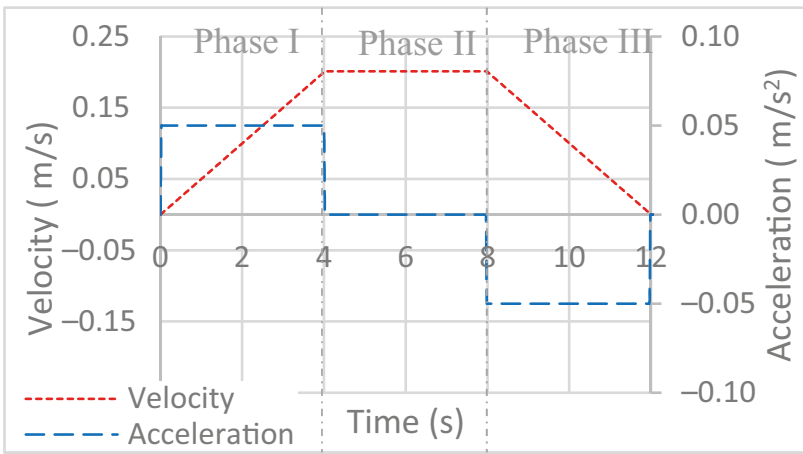

Fig. 1. Trapezoidal velocity profile

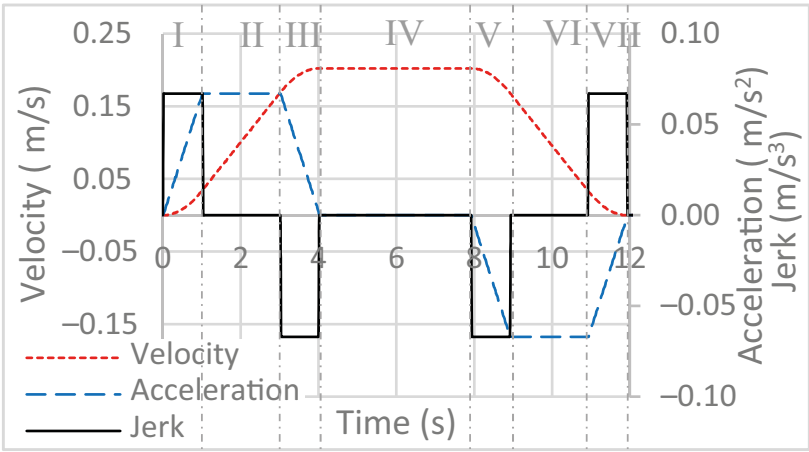

Fig. 2. S-shaped velocity profile

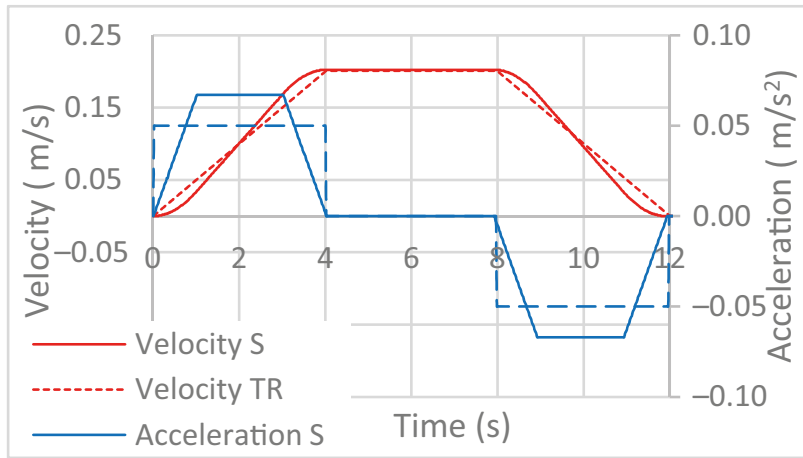

Fig. 3. Compared trapezoidal and S-shaped velocity profiles 

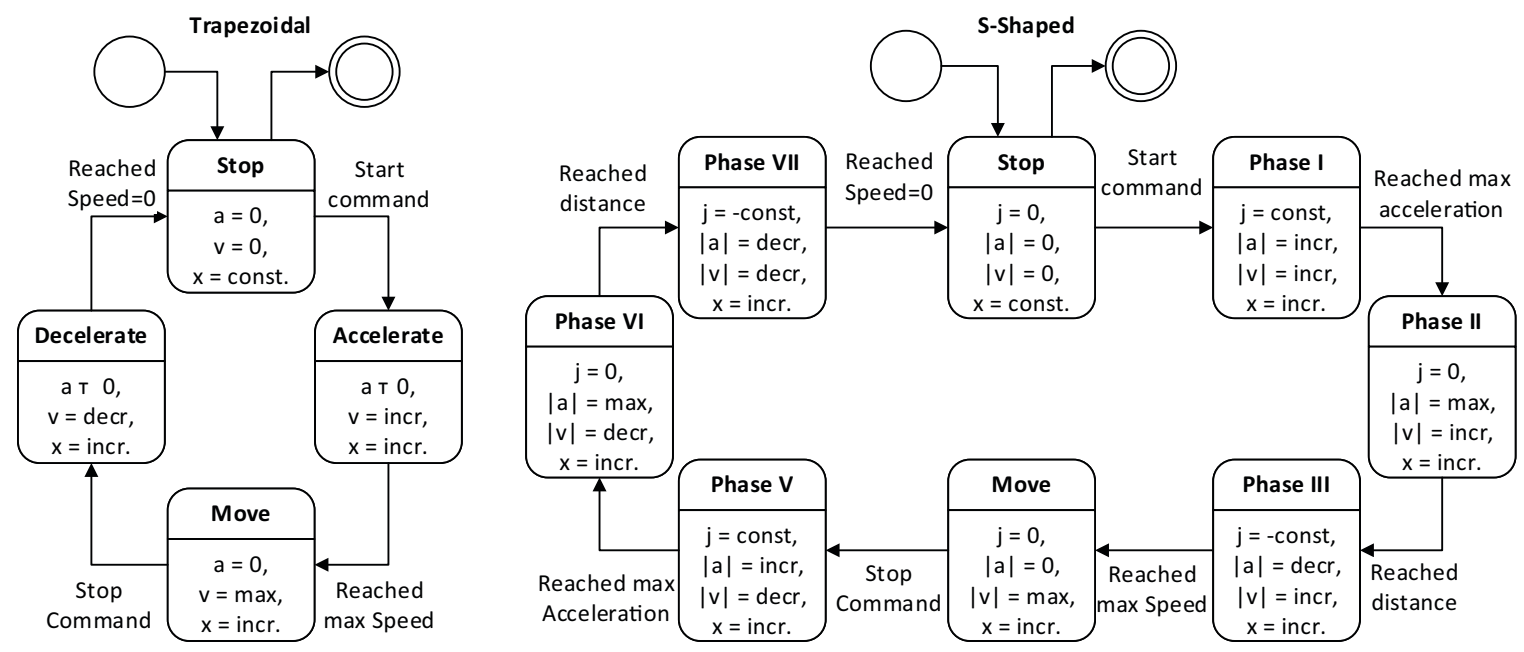

Fig. 4. State machines diagrams used for implementation of trapezoidal and S-shaped velocity profiles for experimental research

The jerk value depends on S-shaped profile phase and it can be $0, j,-j$.

The quay crane control system recalculates the acceleration, velocity and position each sample period.

$$
\begin{gathered}
a=a_{0}+j \cdot \Delta t \\
v=v_{0}+a_{0} \cdot \Delta t+\frac{j \cdot \Delta t^{2}}{2}, \\
x=x_{0}+v_{0} \cdot \Delta t+\frac{a_{0} \cdot \Delta t^{2}}{2}+\frac{j \cdot \Delta t^{3}}{6},
\end{gathered}
$$

here $a_{0}$ - previous acceleration value, $\Delta t$ - sample period, $v_{0}$ - previous acceleration value, $x_{0}-$ previous position value.

As depicted in Fig. 4 state machine diagram based on trapezoidal motion profile (Fig. 1) of control system, has four main states, where the stop state is initial. After the start command has been received, system executes the acceleration state, where the acceleration is positive. The system jumps to move state when the max speed is reached, where the acceleration is zero. After the target point has been reached, the system jumps to deceleration state, where acceleration is negative. Finally, when the velocity reaches zero value, the system goes to stop state. Different from trapezoidal based state machine diagram, S-shaped profile, has eight main states, where the stop and move states are same as in later case. Other phases are based on jerk control. Depending on the current phase, jerk can be positive, negative or zero. Because of these extra phases we have variable acceleration and as the result S-shaped velocity profile (Fig. 2) is generated.

The block diagram of control algorithm are presented in Fig. 5. For better conditions of both experiments the same control algorithm was implemented, where the motion is initiated by required distances. Here the processes begins from Z-axis motion. At the target position (TP) Z1, Y-axis motor turned on while reached TP-Y2. Z-motor is stopped at TP-Z2 (container reached the highest point). When the container position reaches TP-Y1, Z-axis motor is activated in reverse direction. After the given point of container is reached, the algorithm is finished.

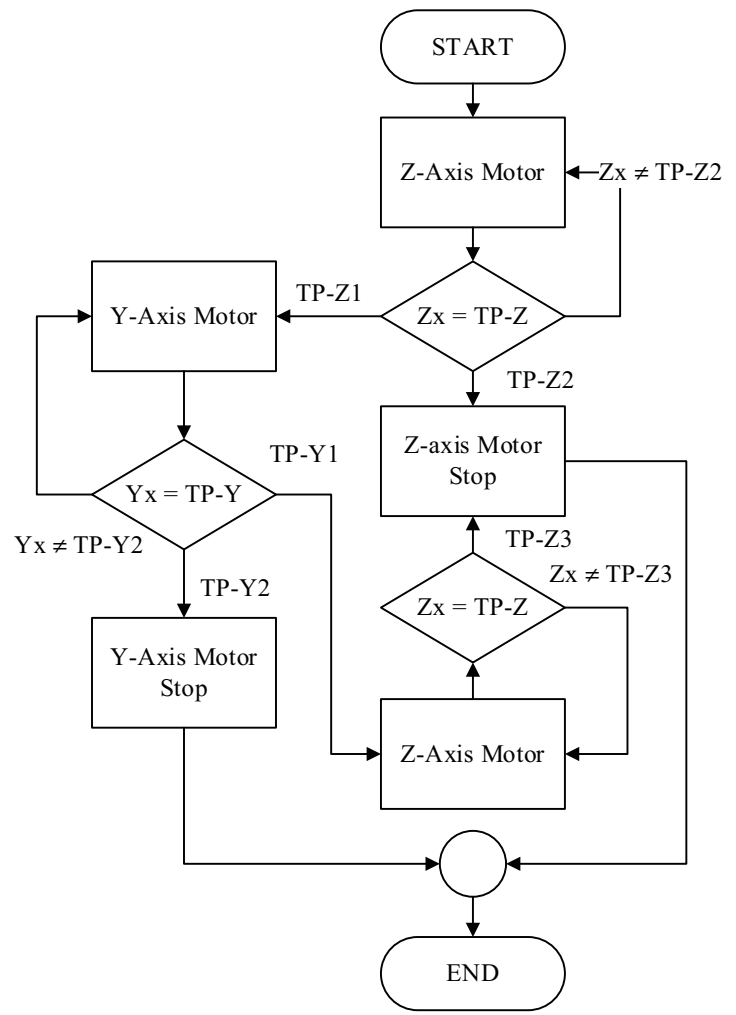

Fig. 5. The quay crane control system algorithm for trapezoidal and S-shaped velocity profiles used for experiment 
While this algorithm is executed, data of container oscillation is collected as well as trolley acceleration, velocity, jerk and position using Arduino Mega controller. Also the container trajectory is calculated and shown in Fig. 6.

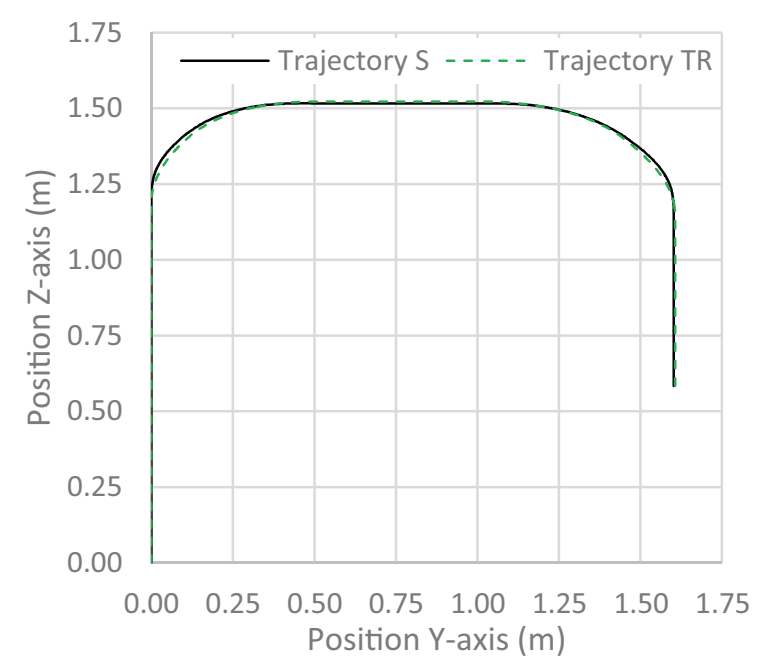

Fig. 6. Container motion trajectory during experiment

Here are presented motion trajectory of trapezoidal and S-shaped velocity profiles. In both cases trajectories match, it means that transportation process was the same, and we are able to compare the results of container oscillation for both profiles.

\section{Experiments and results}

During the experiments, container was lifted up to $1.52 \mathrm{~m}$ height (by Z-axis), transported by Y-axis $1.61 \mathrm{~m}$ distance and finally lowered down to $0.58 \mathrm{~m}$ height (by Z-axis). This case was used with both profiles. The results of trapezoidal velocity profile are depicted in Fig. 7, where the oscillation dependency from Y-axis velocity is presented. Green (square doted) line indicates container oscillation of Trapezoidal velocity (TR) profile by Y-axis, red (long dashed) line velocity of Z-axis, blue (solid) line - velocity of Y-axis. The results of S-shaped velocity profile are depicted in Fig. 8, where black (square doted) line indicates container oscillation of S-shaped velocity (S) profile by Y-axis.

During the handling, first Z-axis motor was switched on. The acceleration lasts $2 \mathrm{~s}$. As presented in both figures (Fig. 7 and Fig. 8), the oscillation by Y-axis, slightly increases, but it has not affected the appearance of the residual oscillation. When the Y-axis motor was turned on, at about $15 \mathrm{~s}$ the acceleration (Phase I) was started. At this moment, the container oscillation suddenly increases. In Trapezoidal profile case, Y-axis activation influences residual oscillation which lasts for a long time period even after the transportation process has ended, contrary to S-shaped profile, where at the Phase III the oscillation was slightly damped, but during the Phase VII, induced again.

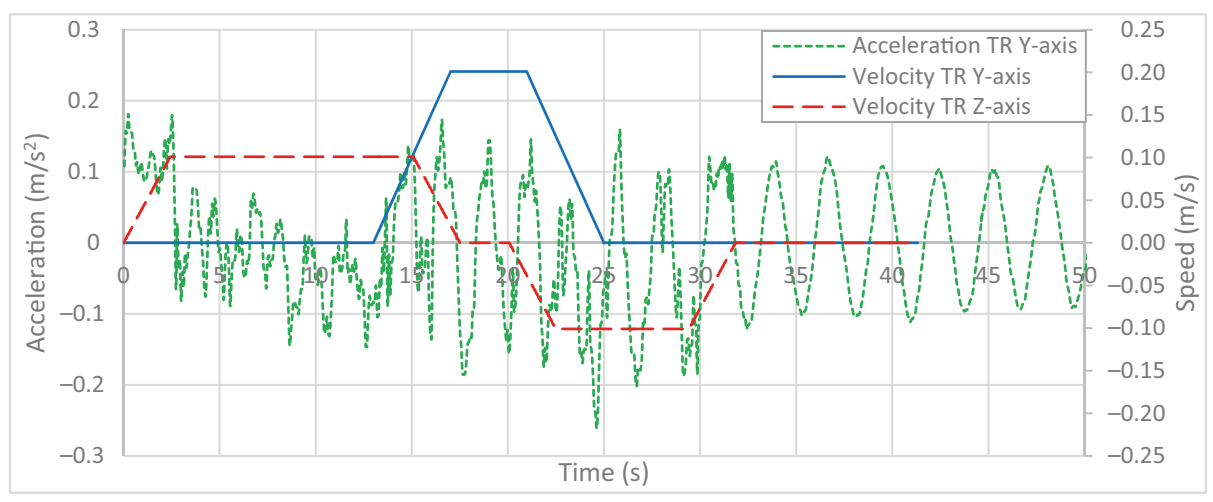

Fig. 7. Experimental results of Trapezoidal velocity profile

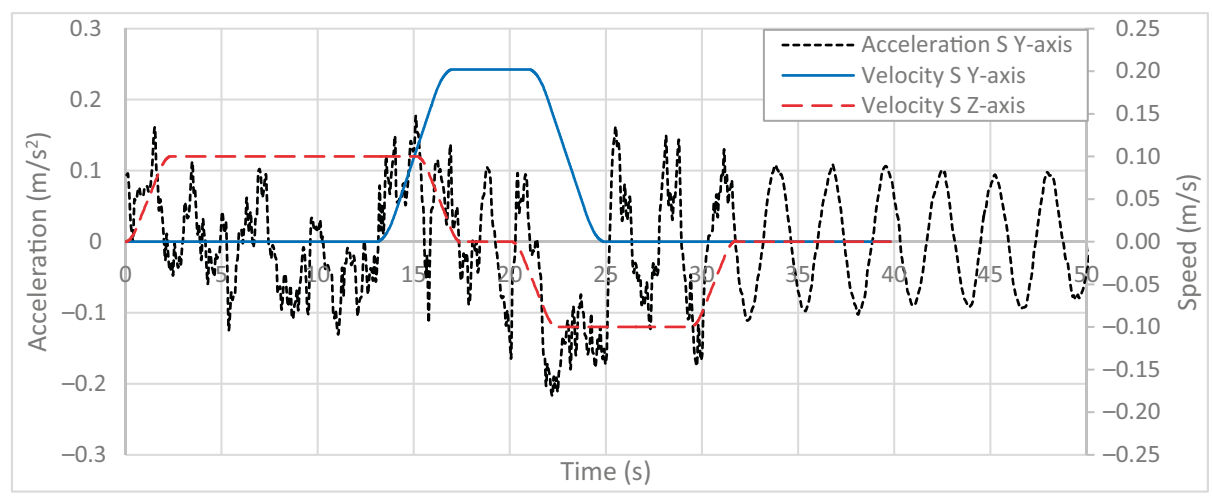

Fig. 8. Experimental results of S-shaped velocity profile 


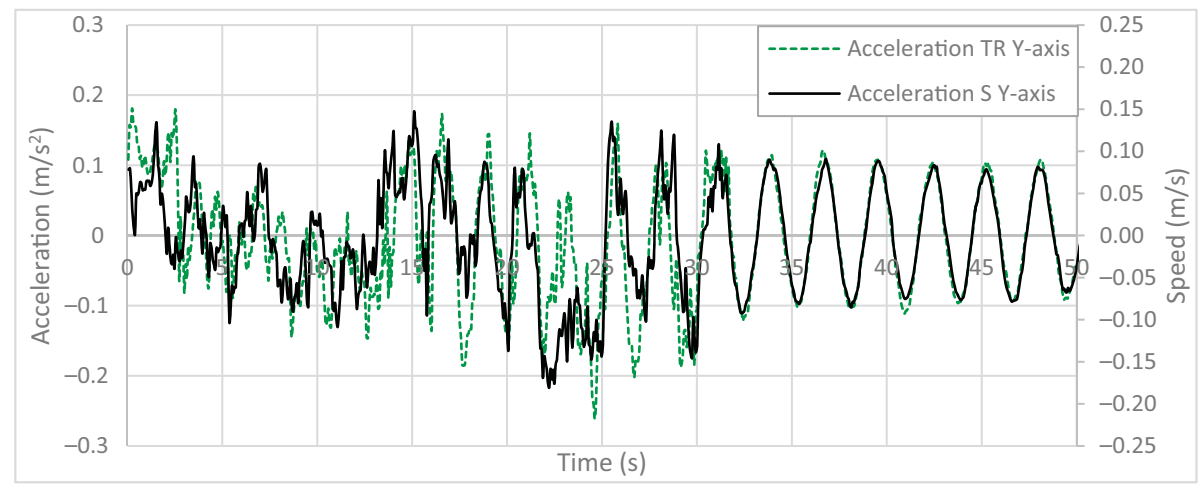

Fig. 9. Oscillation comparison

Comparing the oscillation dependency from Y-axis velocity in both cases (Fig. 9), the residual oscillation after transportation process are similar. A complicated crane system where the cargo is suspended by cables, may cause the results. The scientific Keun-Ho Rew (Rew et al. 2009) S-shaped velocity profile applied to the robot manipulator to control a rigid beam which is made of stainless steel. In our case, S-shaped velocity profile applied to quay crane spreader to control the oscillation of cargo which is flexible connected by cables. The smoothness of trolley was improved as well as Keun-Ho Rew (Rew et al. 2009), however the residual oscillation still remains.

\section{Conclusions}

This paper investigated two different velocity profiling techniques used for quay crane control. The trapezoidal and S-curve velocity profiles were derived for improving the smoothness of the cargo motion. The trapezoidal velocity profile (Y-axis) influences residual oscillation that lasts for the long time period even after the transportation process has ended. Using S-shaped velocity profile at the Phase III the oscillation was slightly damped. In the results of cargo oscillation comparison we can assume that S-shaped velocity profile improves the smoothness of trolley motion, however has no evident effect for residual oscillation reduction. Through the experiments, the effectiveness of the proposed S-shaped profile has to be extensively researched in the future works, by changing transportation speed, adding symmetricities or decreasing the acceleration and deceleration phase durations.

\section{References}

Béarée, R. 2014. New damped-jerk trajectory for vibration reduction, Control Engineering Practice 28(1): 112-120. https://doi.org/10.1016/j.conengprac.2014.03.010

Elbadawy, A. A.; Shehata, M. M. G. 2015. Anti-sway control of marine cranes under the disturbance of a parallel manipulator,
Nonlinear Dynamics 82(1): 415-434.

https://doi.org/10.1007/s11071-015-2165-3

Jaafar, H. I.; Sulaima, M. F.; Mohamed, Z.; Jamian, J. J. 2013. Optimal PID controller parameters for nonlinear gantry crane system via MOPSO technique, in Proceedings 2013 IEEE Conference on Sustainable Utilization and Development in Engineering and Technology (CSUDET), 30 May-1 June, 2013, Selangor, Malaysia, 86-91. https://doi.org/10.1109/CSUDET.2013.6670992

Jaafar, H. I.; Mohamed, Z.; Abidin, A. F. Z.; Ab Ghani, Z. 2012. PSO-tuned PID controller for a nonlinear gantry crane system, in Proceedings 2012 IEEE International Conference on Control System, Computing and Engineering (ICCSCE), 23-25 November, 2012, Penang, Malaysia, 515-519. https://doi.org/10.1109/ICCSCE.2012.6487200

Majid, M. A.; Ibrahim, W. S. W.; Mohamad, S.; Abu Bakar, Z. 2013. A comparison of PID and PD controller with input shaping technique for 3D gantry crane, in Proceedings 2013 IEEE Conference on Systems, Process and Control (ICSPC), 13-15 December, 2013, Kuala Lumpur, Malaysia, 144-148. https://doi.org/10.1109/SPC.2013.6735121

Rew, K. H.; Ha, C. W.; Kim, Y. S. 2009. A practically efficient method for motion control based on asymmetric velocity profile, International Journal of Machine Tools and Manufacture 49(7-8): 678-682. https://doi.org/10.1016/j.ijmachtools.2009.01.008

Sun, N.; Fang, Y.; Zhang, X.; Yuan, Y. 2011. Phase plane analysis based motion planning for underactuated overhead cranes, in Proceedings 2011 IEEE Internationai Conference on Robotics and Automation, 9-13 May, 2011, Shanghai, China, 3483-3488. https://doi.org/10.1109/ICRA.2011.5979526

Sun, N.; Fang, Y.; Zhang, X.; Yuan, Y. 2012. Transportation task-oriented trajectory planning for underactuated overhead cranes using geometric analysis, IET Control Theory \& Applications 6(10): 1410-1423. https://doi.org/10.1049/iet-cta.2011.0587

Wong, T. T.; Tang, C. H. H.; Mailah, M. 2012. Winch driven active heave compensation for load transfer in overhead crane system, in Proceedings ICIAS 2012-2012 4th International Conference on Intelligent and Advanced Systems: a Conference of World Engineering, Science and Technology Congress (ESTCON), 12-14 June, 2012, Kuala Lumpur, Malaysia, 1: 34-39.

Wu, Z.; Xia, X. 2014. Optimal motion planning for overhead cranes, IET Control Theory \& Applications 8(17): 1833-1842. https://doi.org/10.1049/iet-cta.2014.0069 
Xing, G. 2011. Research on application of fuzzy PID in collective pitch control system, in Proceedings 2011 International Conference on Control, Automation and Systems Engineering (CASE), 30-31 July, 2011, Singapore, 1-4.

Xuebo, Z.; Fang, Y.; Sun, N.; Sun, M. 2013. A pseudospectral time-optimal motion planner for underactuated overhead crane systems, in Proceedings of the 32nd Chinese Control Conference, 26-28 July, 2013, Xi`an, China, 3: 4397-4402.

\section{KRANTINĖS KRANO VEŽIMĖLIO JUDE்JIMO \\ VALDYMAS TAIKANT S FORMOS GREIČIO PROFILI \\ SIEKIANT PALYGINTI KRANTINĖS KRANO KROVINIO SVYRAVIMUS}

\section{T. Eglynas, M. Bogdevičius, A. Andziulis, M. Jusis}

\section{Santrauka}

Krantinès kranai yra naudojami konteineriams transportuoti iš laivo į krantą siekiant užtikrinti minimalų krovos laiką taip, kad krovinys pasiektų savo tikslą esant minimaliems svyravimas. Atliekant tokius krovos darbus krantinès kranu konteineris kabo ant lynų, todèl dèl transportavimo judesiu gali atsirasti svyravimų. Šiame darbe analizuojami du skirtingi greičio profiliai, naudojami krantinès krano vežimèlio judesiui valdyti ir kroviniui stabilizuoti. Eksperimentiniams tyrimams buvo panaudotas mažesnio mastelio laboratorinis krantinès krano modelis, kuriame valdomas vežimèlio pagreitis naudojamas konteinerio svyravimams slopinti. Darbe analizuojama išliekamujų svyravimų problema ir skirtingu greičio valdymo profilių ịtaka šiems svyravimams.

Reikšminiai žodžiai: konteinerinis kranas, krovimo procesas, konteinerio svyravimai, eksperimentinè analize, valdymo sistemos, greičio profiliavimas, trapecinis profilis, $\mathrm{S}$ formos profilis. 